\title{
Children's Turn to Participate! Educational co-design with children
}

\author{
¡Le toca participar a los niños! Co-diseño educativo con niños
}

Hanna Kapanen

\begin{abstract}
"At the Design Museum, we at first looked at an old hospital room designed by Alvar Aalto. It was quite cold and formal, just white everywhere. We started to think how to make the patient room more cheerful. We also wanted the room to be comfortable and thought about comfort and possibilities to rest and have privacy." CHILD, November 11th 2014
\end{abstract}

Introduction

Museums are places for creating a link between past and present. Museums are also ideal places to have conversations about the future. Design Museum Helsinki is the national specialist museum for design in Finland. It is a place where you can learn about design. The museum offers learning programmes where children and young people are invited to use their creativity, problem solving and act like designers. ${ }^{1}$ New ways of teaching and talking about design are actively developed within the museum context in order to build bridges from design history to contemporary design practice. Design Museum's educational mission is to promote people's understanding of design and design history by increasing design literacy. The museum is working on this mission in collaboration and in relationship with its partners and the public.

In 2014-2016 the museum created a venue for a series of co-design workshops with children. I, as Educational Curator of the Design Museum and design educator had mutual interest with designer Aino Kiviranta to investigate the role of children in design. As a team we piloted and explored possibilities to integrate children's ideas into design process of the New Children's Hospital in Helsinki, Finland. Enabling children's participation was the central aim of the Children's Turn workshops co-instructed by myself and Kiviranta. The workshops were to create a platform for knowledge production and engaging children in the design process. The children's ideas were to inspire designers and manufacturers to create new kinds of hospital products for children.

My research about the project Children's Turn to Participate! Educational co-design with children investigated the role of

\footnotetext{
${ }^{1}$ Design Museum's and Ornamo's joint project Design Kiddie Academy, Design Museum's School Programme.
} 
children and young people in design, and children's rights to take part and influence the planning, realisation and development of services and milieus directed at them (UN 2009, Pollari 2016). It was a case study that combined research with planning and organising co-design workshops for children and young people (Children's Turn workshops). Facilitating effective participation enables children and young people to have a voice and agency. It also helps service providers make sure that what they do is wanted and required. The significance of participation lies in enabling children and young people to have influence and bring about change. (Packham, 2008, 69.) Today the New Children's Hospital, SARC Architects, Architect Group Reino Koivula (2017) is the leading provider of specialized health care for pediatric patients in Finland. It is the Finlandia Prize for Architecture 2018 winner. The design of the hospital wear of the New Children's Hospital is based on the Children's Turn workshops and children's ideas gained with the aid of co-design and design education.

Design has profound impact on our daily lives. Good design can improve people's health and quality of life. (Salonen, H. et al. 2011.) Historical design collections make evident how the transformative power of design makes an impact in people's daily lives in the past, present and in the future. The connections between design and innovation and childhood development and well-being can be surveyed. Design Museum's collection of Finnish design gives examples of design for children's well-being and health such as the government issued "baby box", a maternity package from Finland, 2012, to ensure safe and healthy care for every newborn in Finland with a concept dating pack to the 1920s. Alvar Aalto's organic, child-sized, easy to clean wooden furniture such as children's chair N65, 1935, used in schools and other institutions such as healthcare centres. Hygienic wooden toys by Jukka-tuote (Jukka-product) such as Hakka-toy, 1946, to trigger playfulness, imagination and kids' desire to explore the world and Marimekko's children's clothing made out of cotton jersey that children can put on and take off themselves to encourage active participation in daily routines and to bring joy with child-friendly bright colours.

Design for children has been a topic of special exhibitions too. Design Museum's main exhibition of the autumn of 2015

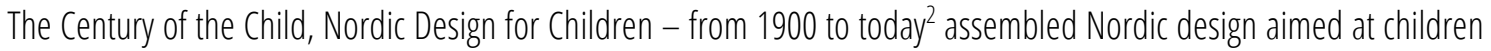
from the early 20th century to the present day. The name of the exhibition came from an international pamphlet published in 1900 by the Swedish social reformer Ellen Key, declaring the 20th century to be the 'century of the child'. The exhibition illustrated the connections between products and environments designed for children and the development of Scandinavian and Nordic society. It featured, among other items, Alvar Aalto's furniture for children, wooden Jukka-toys, Moomin books, Reima's outdoor clothing for children, together with school architecture, playgrounds and public spaces, health-care and safety products, and aids for the disabled children.

Design Museum's exhibition Healing in the beginning of 2018 showcased design to support people's health. Healing was an exhibition of Finnish and Scandinavian design from the 1930s to the present day. It considered health, illness and healing as a broad phenomenon of various levels from the perspective of design. The exhibition posed the question of how the designed environment affects us as humans. This exhibition featured, among other items, Alvar and Aino Aalto's Paimio Tuberculosis Sanatorium, 1929-1933 and some of its furniture, Eino Kauria's colour scheme for Paimio Sanatorium, 1933, Com-pa-ny's Flower vase tree, 2016 for the Espoo Hospital and Tove Jansson's sketches for a mural produced for Aurora Children's Hospital in Helsinki in 1955-1956 when Jansson painted the ceiling of the EEG room with squirrels and the staircase with Moomin characters. Jansson's mural painting instruction reveals what and for

\footnotetext{
${ }^{2}$ Century of the Child - Nordic design and Children 1900 to today; Museum Vandalorum, Sweden May 10-Sebtember 28, 2014; Designmuseum Danmark, Denmark, November 28, 2014-August 16, 2015; Design Museum Helsinki, Finland, October 9, 2015-January 17, 2016; The Nordic House, Iceland, July 22, 2016-February 27, 2017; V\&A Museum of Childhood, England, March 30-September 2, 2018.

${ }^{3}$ Healing; Design Museum Helsinki, Finland, January 26-March 11, 2018.
} 
whom was the design for: "The painting in the staircase of the building should engage the children in a way that would make them forget the fact that they have entered the hospital. The piece should also be of such artistic quality the children would be inspired to climb the stairs upwards to find out what else the scene holds. This way the children would almost unwittingly climb to the second floor, and enter the lobby, which is designed to look like a playroom."."

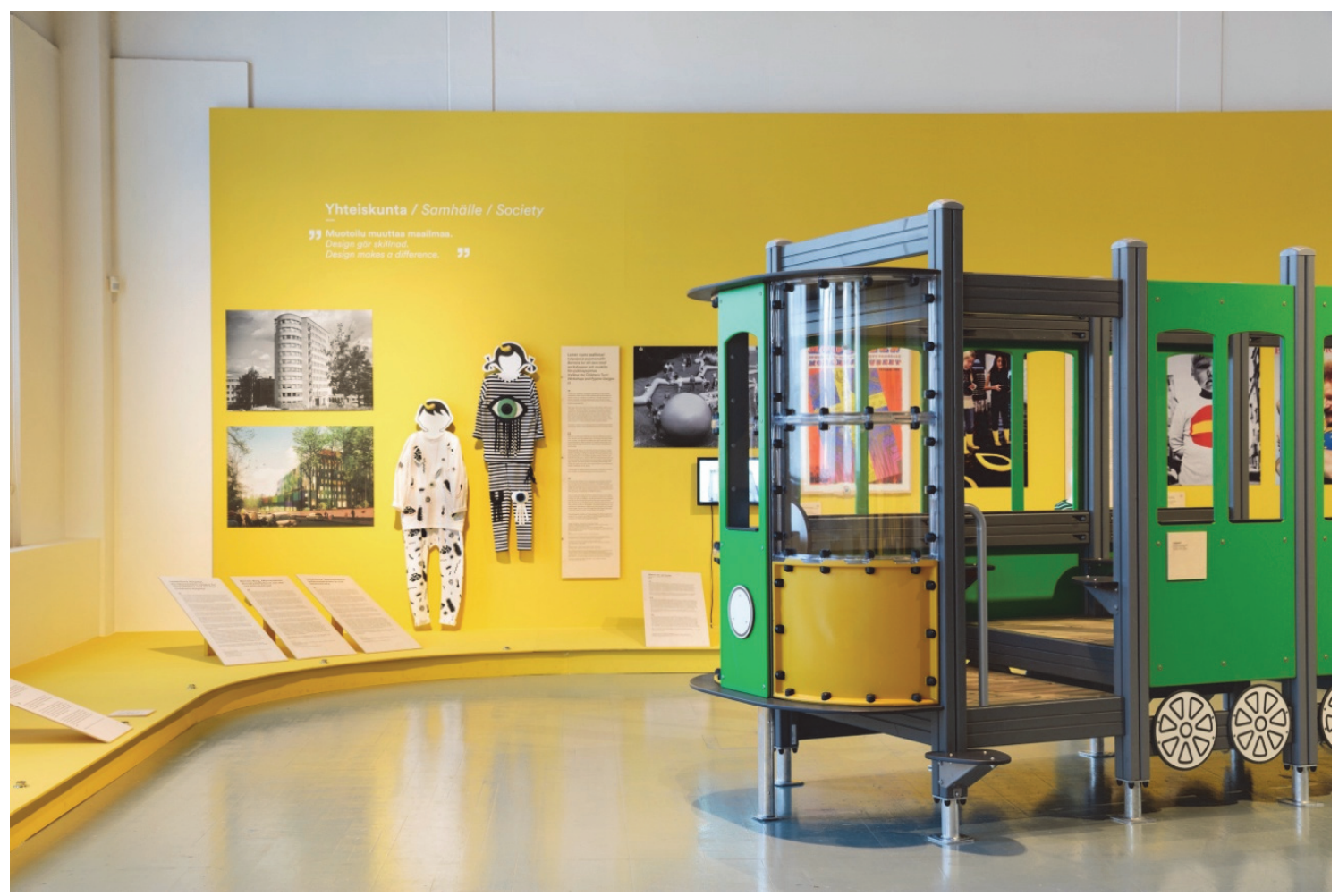

Figure 1. Exhibition Century of the Child - Nordic design and Children 1900 to today; Design Museum Helsinki, Finland, October 9, 2015-January 17. Prototypes for hospital wear based on the children's ideas on the wall. Photo: Paavo Lehtonen.

Both exhibitions The Century of the Child, Nordic Design for Children - from 1900 to today and Healing featured pieces with roots in the Children's Turn project. The Century of the Child, Nordic Design for Children - from 1900 to today exhibited the co-design method and the very first ideas of what could the hospital wear based on the children's ideas look like. The patterns of the designs presented were created by designer Maija Louekari from ideas submitted by children and collected from the pilot workshops in 2014. Prototypes for the pajamas exhibited were made by Marjut Rahkola, Vimma.

The Healing exhibition featured examples of the prototypes for the final designs of the hospital wear of the New Children's Hospital. These were prototypes for a children's gown, a robe and pajamas created by designers Paola Suhonen and Piia Honkanen of Ivana Helsinki based on the ideas submitted by children. This design process commenced at the final Children's Turn workshops held at the Design Museum in the spring of 2016. These final workshops were organised by the Association of Friends of the University Children's Hospitals, allowing the children's

${ }^{4}$ Exhibition text, Healing; Design Museum Helsinki, Finland, January 26-March 11, 2018. 


\section{taphiya $\mathbf{4 7}$}

ideas to be submitted to the final designs of the new hospital wear. The designers Suhonen and Honkanen were actively involved in the co-design together with the children.

Both exhibitions included also a glimpse to the history of children's hospitals in Helsinki featuring architecture for Lastenlinna (Children's Castle) designed by architects Elsi Borg and Olavi Suortta, 1948 and the plans and visualizations for the upcoming new children's hospital.

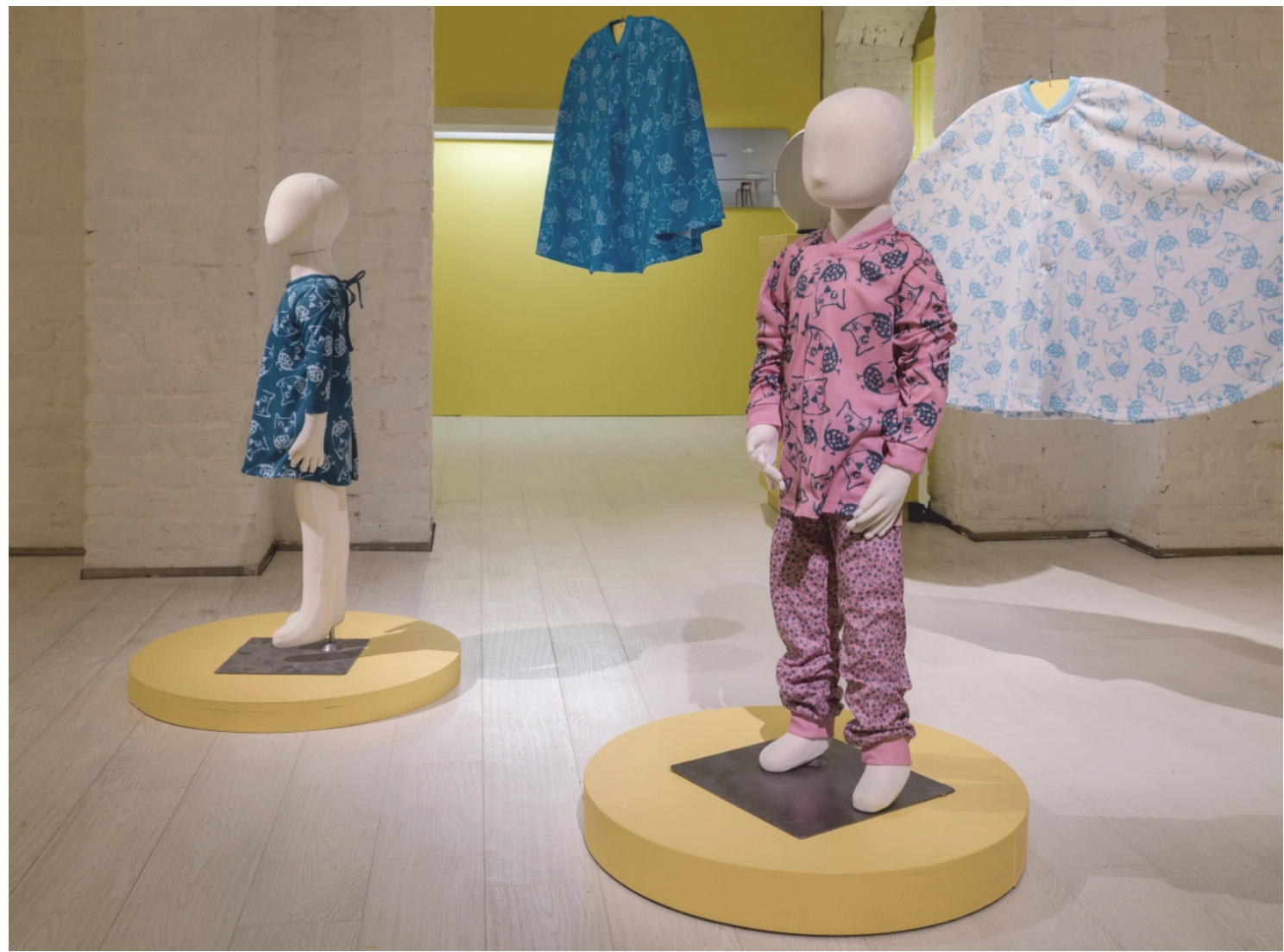

Figure 2. Healing exhibition. Prototypes for children's gown, robe and pajamas for the New Children's Hospital 2017. Designers: Paola Suhonen and Piia Honkanen, Ivana Helsinki. Manufacturer: Uudenmaan sairaalapesula Oy. Photo: Sergio Urbina.

Sanders and Stappers (2008) state that designers have been moving increasingly closer to the future users they are designing for. Many contemporary designers are co-designing with the end-users. The evolution in design from a usercentered approach to co-designing is changing the design practice. I think it is also changing the way we exhibit, interpret and learn design. It may influence the creative ways museums engage with their audiences too.

\section{Concept of Participation related to children's rights}

The Children's Turn to participate! Educational co-design with children investigated the role of children and young people in design, and children's rights to take part and influence the planning, realization and development of services and milieus directed at them (UN 2009, Pollari 2016). 


\section{tarbiya $\mathbf{4 7}$}

Article 12 of the Convention on the Rights of the Child (1989) states that children have the right to participate in decision-making processes that may be relevant to their lives and to be able to influence decisions as a member of a family, as a pupil at school or as a member of their community. The child's own thinking should be valued. We need to accept that the child's view may differ from his or her family's views or from any adult's opinions. The child's own ability to think, communicate and make decisions from a very early age needs to be understood. (Lansdow 2010, 12.) This is a strong argument on how essential it is to place special focus on children's participation.

In a blog post for Finland's Central Union for Child Welfare Kirsi Pollari wrote about how children's participation leads towards more sustainable development. The Committee on the Rights of the Child has stressed that the right of the child to participate and influence matter under Article 12 should also be extended to the design, implementation and development of services and environments for children. (Pollari 2016.) In her annual report for 2013 the former Ombudsman for Children in Finland Marja Kaisa Aula encouraged designers, decision-makers and professionals from different administrative sectors to take into account the experience of children and young people. Understanding children's experience helps adults develop services aimed at children. Aula's report encouraged testing and piloting new ways to involve children in design processes directed at them. (Aula, 2013.)

\section{Children's Turn workshops}
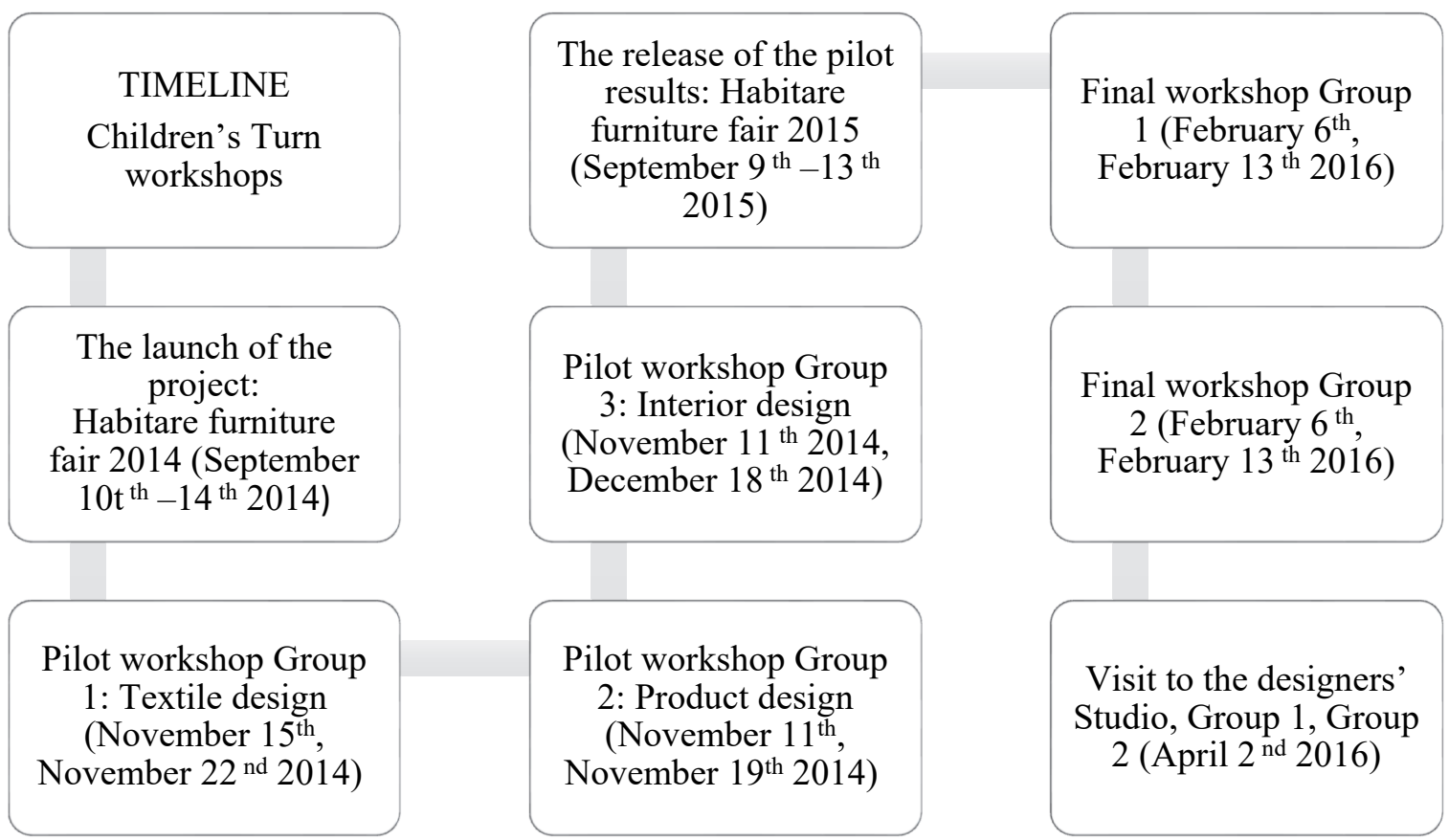

Figure 3. Timeline to illustrate the main events of the Children's Turn workshops.

Children's Turn workshops (2014-2016) explored possibilities to integrate children's rights into design processes. The core idea was to find out what would happen if children and young people were invited to a series of co-design workshops supported with design education where children ideate and design the hospital environment of their dreams together with design professionals. The workshops were carried out with a grant for children's culture admitted 
by Arts promotion centre Finland $(2014,2015)$. The aim was to develop and test methods to allow children's participation in design. Stepping into the user's shoes is at the core of the human-centered design and empathy was chosen as a starting point for the work followed with ideation, sketching, prototyping and testing.

A simple set of cards was created to aid children in sharing ideas on the design of the hospital environment. This way the children's thinking could be saved and analysed afterwards. Situations faced by young patients were approached through fictional characters Saara and Otto, who had to go to the hospital. Saara was afraid the tests would hurt, and Otto was afraid to sleep at the hospital. The children taking part in the workshop put themselves in Saara's and Otto's position and imagined what might comfort them and make them feel happy. The aim was to experiment and demonstrate how emotions and empathy towards Saara and Otto was conceptualized in design of a patient's room. The key working method was to utilize design thinking, to look at the subject through "designer's spectacles" (Perez 2013) and designing with emotions (Salovaara, 2013).

\section{SAARA JA OTTO}

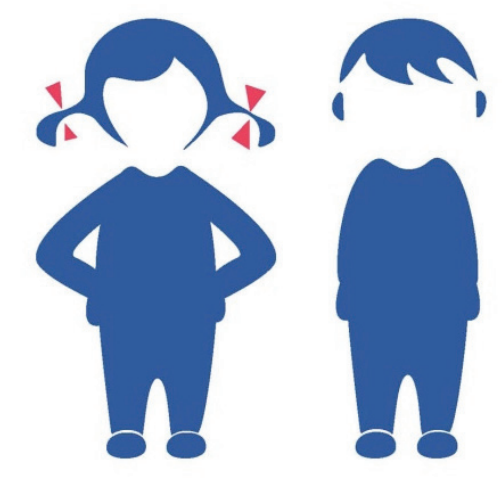

Saara ja Otto ovat joutuneet sairaalaan. Saaraa jännittää sattuvatko tutkimukset ja Ottoa pelottaa nukkua sairaalassa.

MIKÄ LOHDUTTAISI JA ILAHDUTTAISI SAARAA JA OTIOA?

Figure 4. Storytelling was applied and used in the workshops. Situations faced by young patients were approached through fictional characters Saara and Otto. Illustration: Aino Kiviranta.
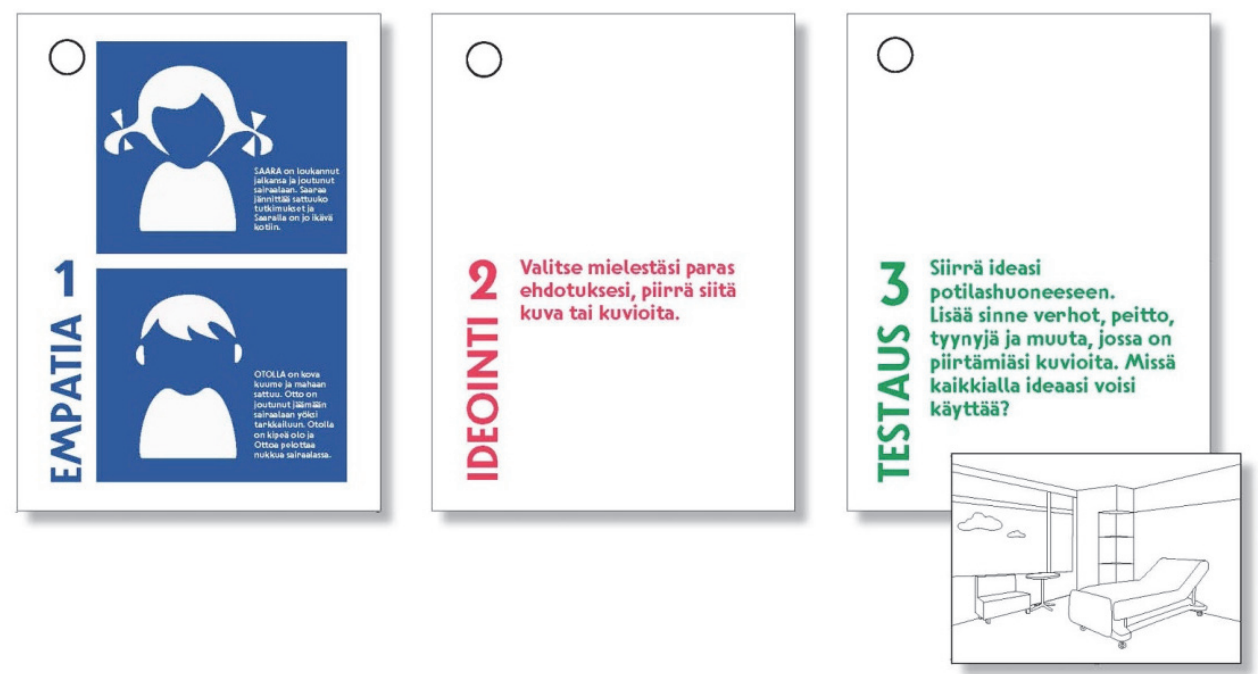

Figure 5. Design tool for the Children's Turn workshops: 1. Empathy, 2. Ideation, Testing. Illustration: Aino Kiviranta. 
The workshop pilots started in 2014 with a nonstop workshop for children and their families at the furniture fair Habitare ${ }^{5}$. The workshop was organized to gain first impressions on how to approach the topic with children. The results of the workshop formed the design drivers for a series of three more in-depth workshops with invited groups of children. 181 children participated the Habitare workshop altogether, and 441 works were done during the fair. An analysis of the works was made after the event. It was based on the outcomes of the workshop; visualizations and written texts. Based on the analysis it was possible to make scenarios of what the children deemed important in the future hospital and what their dream hospital would look like. According to the analysis privacy emerged as a central issue, described in many cases as a shelter to give you peace (186 mentions). The importance of colours was prominent (186 mentions). The possibility to make certain choices for yourself whilst hospitalized; such as being able to pick a theme for a room (100 mentions) and bringing comfort and joy to the patient; comforting and soothing messages, teddy bears and other comforting elements (62 mentions). Based on the analysis the children's dream hospital seemed to meet many needs pointed out also by the parents and the experts. ${ }^{6}$

As a continuation of the Habitare workshop 60 children altogether participated the pilot workshops at the Design Museum in the autumn of 2014, and one of the workshops was organized at a school. The participants for the pilot workshops at the museum were invited from two schools and one group was invited with an open call for families especially targeting families with children with long term illnesses. The textile design workshop tested how stories created by children were conceptualized in design. The product design workshop offered new ideas to improve the patient experience with the aid of product design. In the interior design workshop children created a child friendly visual language to guide you around at the hospital. Each group met twice, and their ideas were further developed by professional designers in the time between. Industrial designer Anna Palomaa, designer and CEO Pekka Toivanen and textile desi
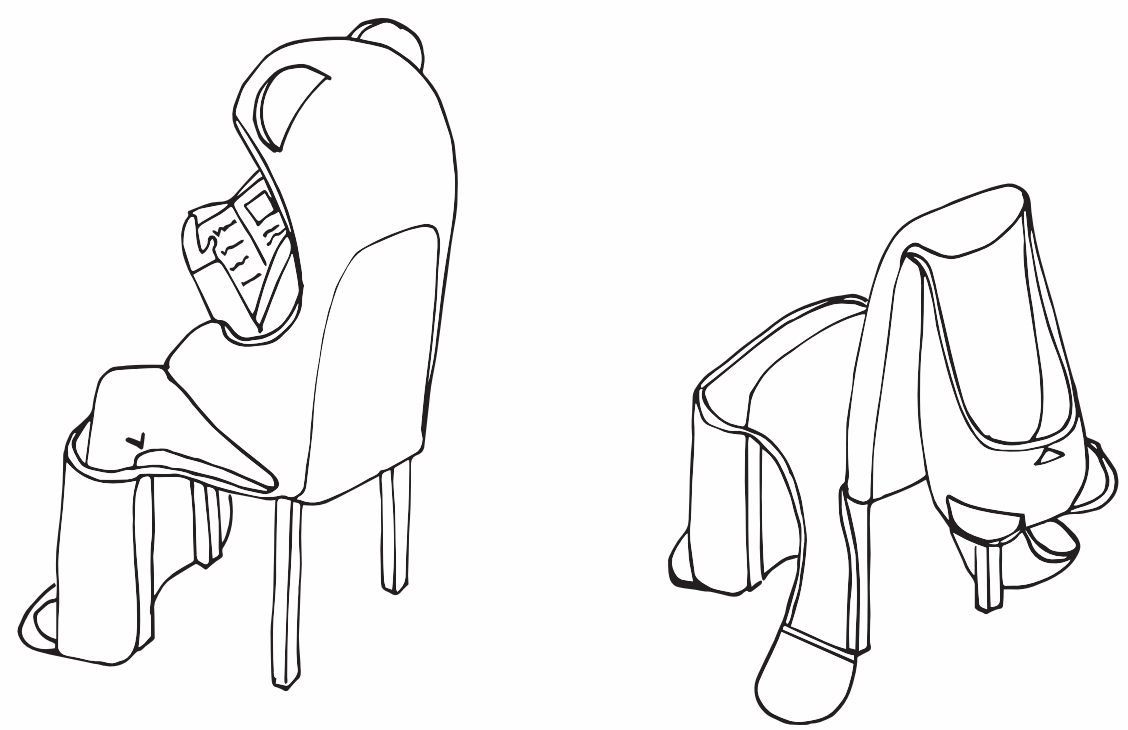

Figure 6. Design tool for the Children's Turn workshops: a bear chair with a textile hood. The illustration based on an idea by children. Illustration: Aino Kiviranta.

5 Habitare - Finland's largest furniture, design and decoration event. Children's Turn was part of the programme, Helsinki, Finland, September 10-14; 2014, September 9-13; 2015.

${ }^{6}$ Parents' needs and expectations for the New Children's Hospital were studied in 2014. The parents' expected the hospital to be first and foremost $35 \%$ respectful of privacy and $28 \%$ designed for children. (Kopla Helsinki, 19.3.2014) 
The museum collection played a central role and all museum workshop pilots started with observing the patient room of Paimio Sanatorium designed by Alvar and Aino Aalto in the Design Museum's collection exhibition. The work continued with a design task tailored for each workshop. The methods of ideation, sketching, prototyping, testing and storytelling were in use. One child describes the experience: "After a number of design stages, the teams got ready to present their ideas. When we went back to the workshop after a week, I was pretty excited because our ideas and models had been developed further to an animal shelter, a bear chair with a textile hood and a lamp shade that reflected birds on the ceiling."

After the workshops, the results and methods were evaluated. The concept and the design tools for educational codesign with children developed to aid children's participation in design seemed to work well and had a strong pedagogical focus allowing children of different ages to express their ideas. The methods had a strong connection with the real-world design practice. An important part of the workshops was meeting the design professionals, learning about their work and collaborating with them. It also seemed that creative expressions of children inspired the designers and gave them new perspectives and ideas.
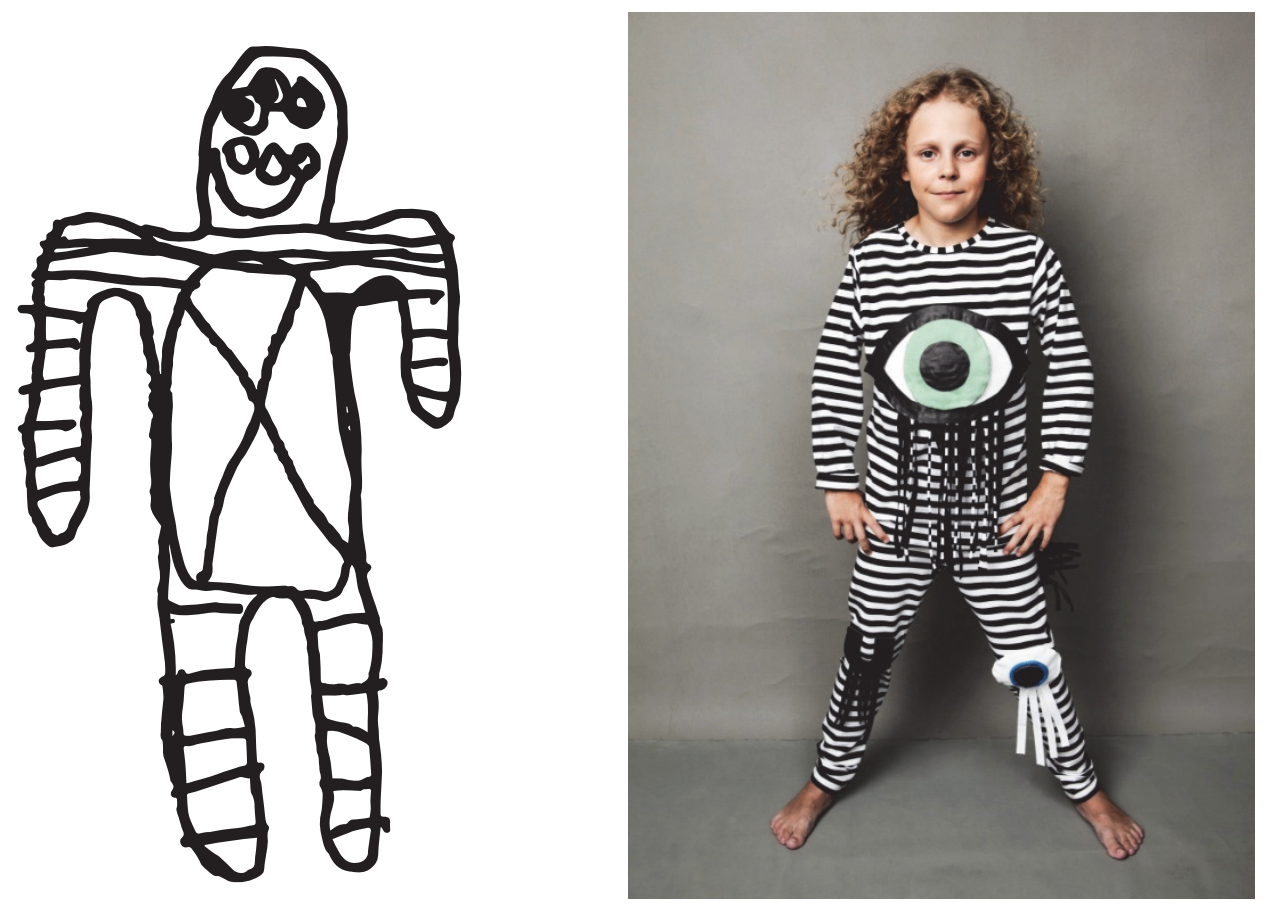

Figure 7. The textile design workshop tested how stories created by children were conceptualized in design. Prototype for a children's pajama based on the children's ideas 2015.

Designers: Marjut Rahola and Maija Louekari. Manufacturer: Vimma. Photo: Outi Törmälä.

The results of the piloted Children's Turn workshops were again part of the Habitare fair in 2015. It was decided to take the co-design on hospital textiles forward and challenge a clothing company to create prototypes to show how children's ideas could enrich the final designs. Finnish textile design company Vimma produced the first prototypes based on the children's ideas. These prototypes were presented at the fair. The prototypes were photographed by Outi Törmälä as worn by the children whose ideas the designs were based on. These photos were also exhibited. Also a new set of cards utilizing user personas as a design tool was tested together with a cardboard hospital as a nonstop workshop for 


\section{taphiya $\mathbf{4 7}$}

children and their families during the fair. The user personas represented the goals and behaviour of a hypothesized group of users: child patients, a doctor and a nurse. The cardboard hospital allowed testing ideas.
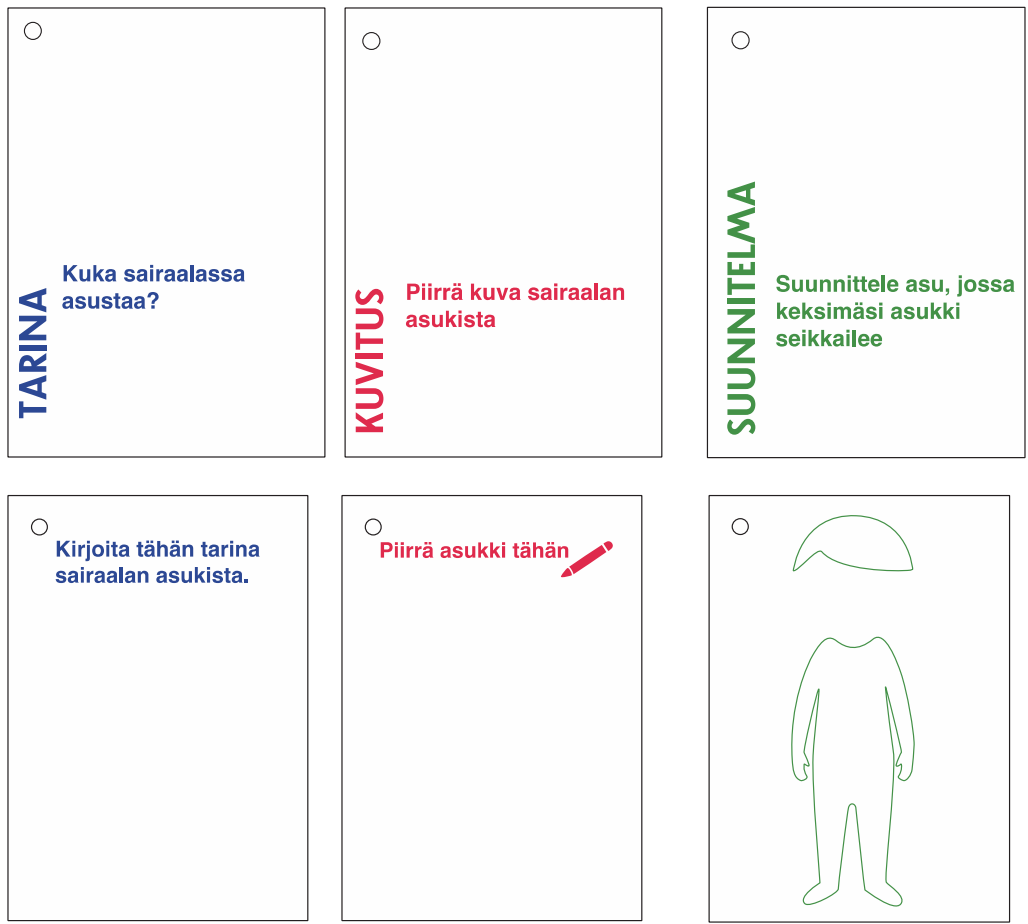

Figure 8. User personas as a design tool was used for this task created for the Children's Turn workshops. Children designed clothes for doctors, nurses and patients. Illustration: Aino Kiviranta.

\section{Final co-design workshops}

The project started with experimenting and piloting methods for children's participation in 2014-2015. Based on the good results gained from the pilot workshops, Children's Turn workshops were invited by the Association of the Friends of the University Children's hospitals, the Kummit charitable organization, to kick off the participatory product development to support the design of the New Children's Hospital's patient wear. The results of the workshops were also presented to the representative of the New Children's Hospital foundation in April 2015.

The final three hour workshops were held consecutively twice each for two groups of fifteen children each at the Design Museum in February 2016. The workshops were especially targeted at families with children with long term illnesses, though all children and young people were welcome. The designers of the collection Paola Suhonen and Piia Honkanen of Ivana Helsinki took part in the workshops. The participants knew that some of the ideas emerged in the workshops would be developed further into final products. This was exciting for them.

The methods tested during the pilot workshops were in use to allow children's participation in design. The workshops started from the museum collection with observing the patient room of Paimio Sanatorium. The work continued with design tasks applying the methods of ideation, sketching, prototyping, testing and storytelling. During the workshops children created a great amount of creative results to inspire design. The material consisted of written stories, drawings, paintings, sketches with details and much more. One participant describes the workshops: "I think this has been very 
interesting. Imagine how a small image and a story can turn into a piece of clothing! I'm super interested in this. I am interested in designing clothes, furniture..."

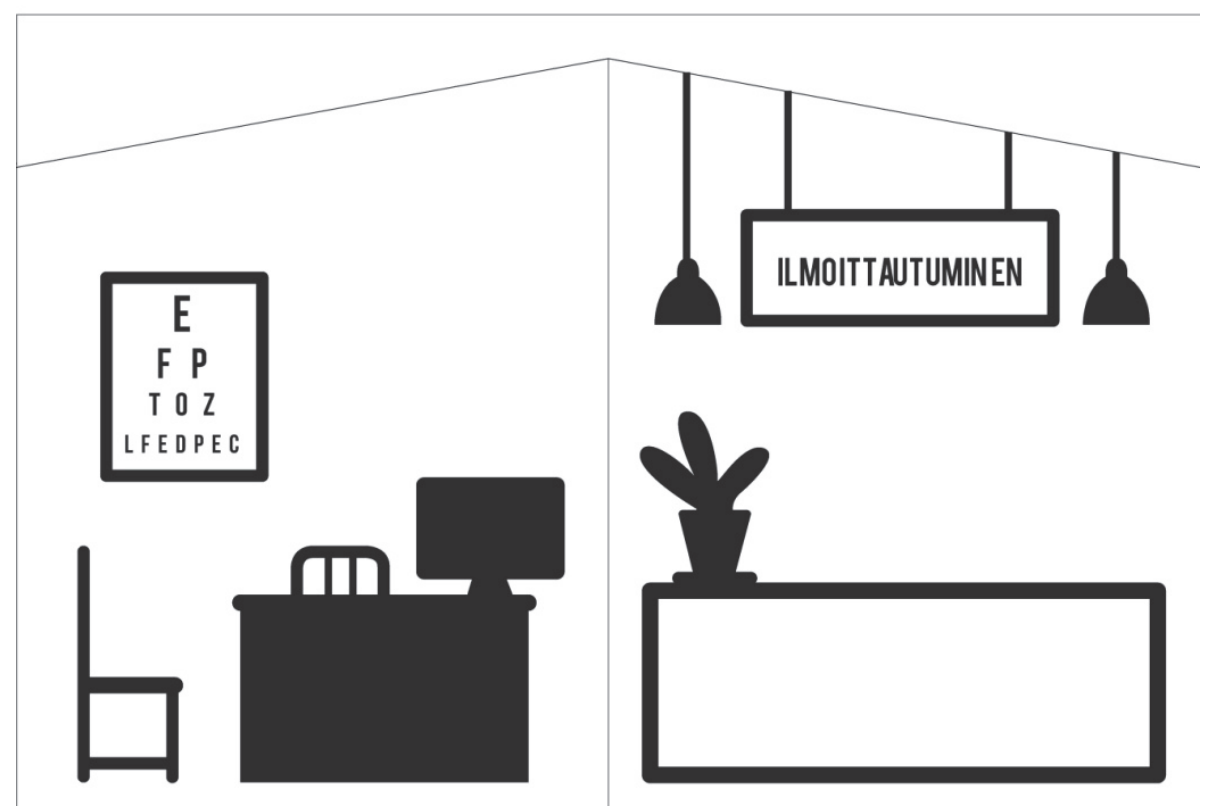

Figure 9. Cardboard hospital as a design tool of the Children's Turn workshops allowed storytelling and testing. Illustration: Aino Kiviranta.

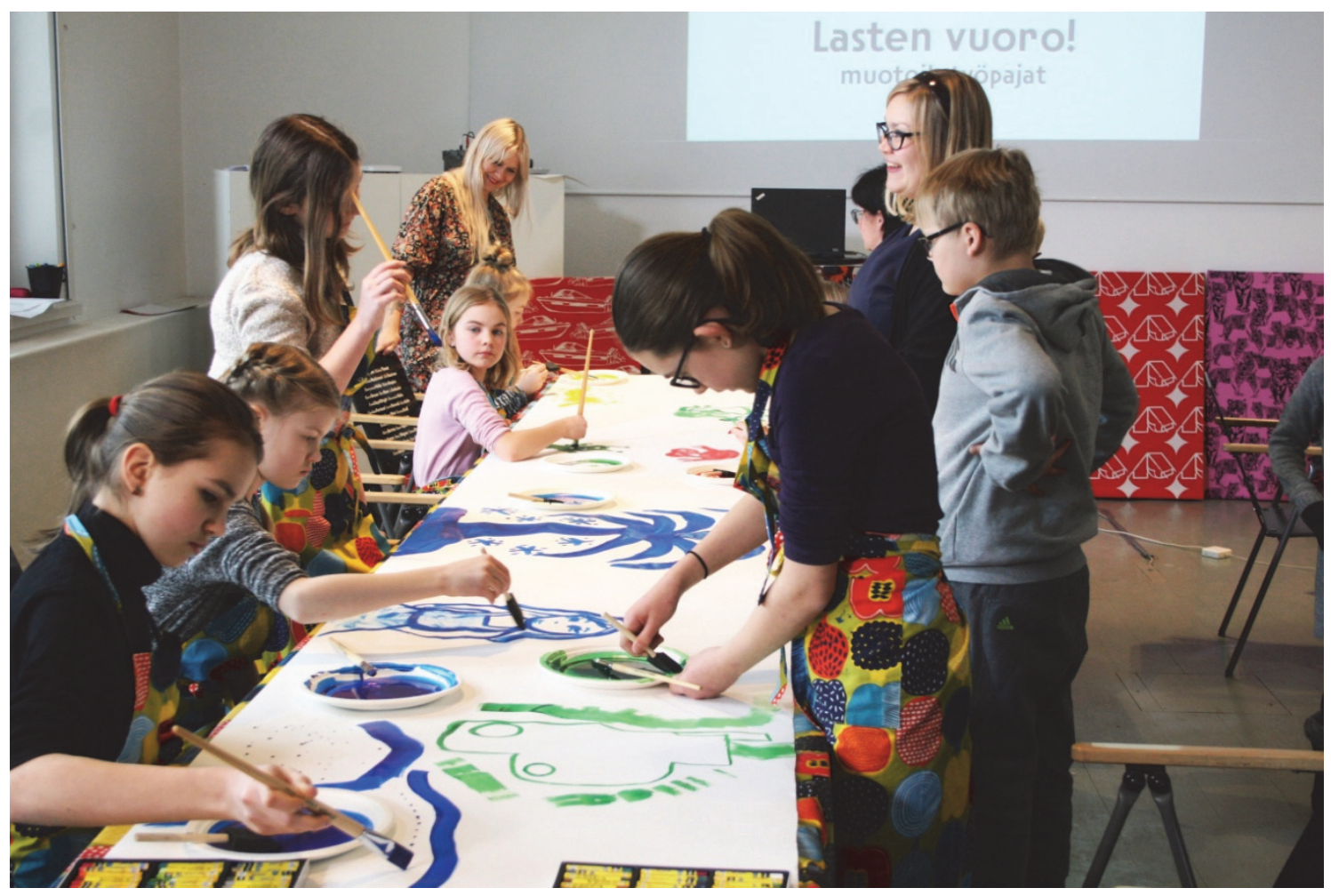

Figure 10. View from the final Children's Turn workshops. Collective painting. Photo: Matti Hannula, Kummit. 
After the workshops both groups were invited to visit the designers' studio in April 2016. All 30 children participating the workshops were invited. They had a chance to tour the studio, and see in real-life how designers worked on their ideas. The moment they all had waited for was voting on children's own favourite designs.

There was a large amount of sketches and it took a while before the participants started to make decisions. When the choices were made it was time to celebrate. In the end children were given diplomas for their participation. Designer Paola Suhonen described the results and her experiences after the project: "It is the most special collection since it was made with children. I have never worked with a design team this big as I did in this project." (Paola Suhonen, conversation, April 4, 2016).

\section{Conclusion}

Article 12 of the Convention on the Rights of the Child (1990) elaborates on the child's right to be involved and taken seriously in decision making (UN 1990). Therefore, my research began with the motivation to promote children's rights to take part and influence the planning, realization and development of services and milieus directed at them through design education and co-design.

In co-design, the roles get mixed. People who will eventually be served through the design process are given the position of experts of their own experiences. A designer and a researcher support the process and provide tools for ideation and expression. (Sanders \& Stappers, 2008, 7). The children were enthusiastically involved in co-design activities co-instructed by me, design educator and researcher, and Kiviranta, designer as experts of their own experiences, to help the designers understand their needs, and to be able to produce child-friendly products for the hospital. Children participating in the project tested different design tools and worked like real designers. It was important to let them learn and experience what designing means, how creative ideas come to professional design, how to work on the ideas and how to develop the ideas further together.

A dialogue with a 7-year-old is very different to one with a 16-year-old and yet we managed to create strong enthusiasm for the subject and to gain a lot of results from children and young people of very different ages. All pedagogical approaches were understood especially as a way to encounter children's and young people's experiences, ideas and dreams. The design tools developed for the project enabled the participants of the workshops to communicate their ideas and feelings. The designer and the design educator collaborated on the tools for generating insights. Both pedagogical approaches and design skills were very important in the development of the tools.

In my perspective, the workshops were successful in creating a platform for knowledge production and engaging children in the design process. The workshop results inspired designers and manufacturers to create new kinds of hospital products for the children. Paola Suhonen describes how "the imagination of children is endless" and how "there were no limitations in their minds". The designer also recognized the special world of children: "This is a reminder that children are also very receptive and experimental as an audience and they also seem to like things that seem a bit odd, in a good way". She pointed out what a rare opportunity it was to get involved with a project like this: "I have never been part of a project in which there are so many designers (children). From a designer's point of view it is interesting when you are given so much material to work with. The most difficult part is to choose what to use and what not to use. In this case it has been an embarrassment of riches, which is rarely the case in the real world."

Designing together with children and young people supports their participation rights. Article 12 of the Convention on the Rights of the Child elaborates on the child's right to be involved and taken seriously in decision making (UN 1990). The Children's Turn workshops aimed at including the end users in the design. This made the process and its results reflect the huge potential of children's and young people's creative input in design and their right to participate. By 


\section{tgphiyg $\mathbf{4 7}$}

involving children in the design process the Children's Turn workshops supported children's rights to take part in and influence the planning, realization and development of services and milieus directed at them.

My research suggests co-design together with design education as a solution for changing design practice to support children's participation. I reckon the Children's Turn workshops turned out to be successful both in creating a platform for knowledge production to engage children in design, and in inspiring designers and manufacturers to create new kinds of products for hospitals. A pedagogical framework and design tools created for the workshops were some of the outcomes of this project. As Lansdown (2010) underlines implementation of Article 12 requires recognition of nonverbal forms of communication such as play, drawing and painting, through which children make choices, express preferences and demonstrate understanding of their environment. Children have the "right to express those views freely". My research suggests co-design and design education for creating this common language, to make sure children are understood in different ways they are able to communicate. With the right design tools, everyone is able to articulate and create, and to express themselves (Sanders 2002).

\section{Acknowledgements}

This article draws on my Master's thesis Children's Turn to Participate! Educational co-design with children supervised by Riikka Haapalainen, Aalto University School of Arts, Design and Architecture 2017. These experiences I shared also in my lecture in the "International Encounter on Childhood + Architecture + education + Inclusion", Reina Sofia, Madrid, 2019. 


\section{Appendix}

\section{TIMELINE}

The launch of the project: Habitare furniture fair 2014 (September 10t th -14 th 2014)

Pilot workshop Group 1: Textile design (November 15th, November 22 nd 2014)

Pilot workshop Group 2: Product design (November 11th, November 19th 2014)

Pilot workshop Group 3: Interior design (November 11 th 2014, December 18 th 2014)

The launch of the results of the pilots Habitare furniture fair 2015 (September 9 th -13 th 2015)

Final workshop Group 1 (February 6th, February 13 th 2016)

Final workshop Group 2 (February 6 th, February 13 th 2016)

Visit to the designers' Studio (April 2 nd 2016) 


\section{Bibliografía}

LANSDOW, G. (2010). The realisation of children's participation rights: critical reflections. En B. Percy-Smith \& N. Thomas (Ed.), A Handbook of children and young people's participation -Perspectives from theory and practice, pp. 12. New York, USA: Routledge.

Malone, K. \& Hartug, C. (2010). Challenges of participatory practice with children. En B. Percy-Smith \& N. Thomas (Ed.), A Handbook of children and young people's participation -Perspectives from theory and practice, pp. 28-30, 32. New York, USA: Routledge.

O'connOR, A. \& SVenle, E. (ED.). (2015). Century Of The Child - Nordic Design For Children 1900 To Today. Värnamo, Sweden: Museum Vandalorum.

Publication of the Office of the Ombudsman for Children 2013:4 (2013). Office of Ombudsman for Children's Action Plan for 2013. Jyväskylä, Finland: Office of the Ombudsman for Children. Available at: http://lapsiasia.fi/wp-content/uploads/2014/12/Action-Plan-for-2013.pdf (Accessed 30 September 2017).

PACKMAN, C. (2008). Active citizenship and community learning. Exeter, UK: Learning Matters Ltd.

PERCY-SMITH, B. \& TOMAS, N. (ED.). (2010). Handbook of Children and Young People's Participation. Perspectives from theory and practice. Abingdon, UK: Routledge.

Perez, Gregory A. (2013). Habitare 2013 ahead! Uusi Lastensairaala. Helsinki, Finland: Messukeskus Helsinki. Video, available at: https://www.youtube.com/watch?v=W4Pgj-QvQqU (Accessed 30 September 2017).

PolLARI, K. (2016). Lapset asialla! - kohti lapsiystävällisempiä palveluita ja lapsille sopivampia ympäristöjä. Lasten suojelun keskusliiton blogi. Available at:

https://www.Iskl.fi/blogi/lapset-asialla-kohti-lapsiystavallisempia-palveluita-ja-lapsille-sopivampia-ymparistoja/ (Accessed 30 September 2017).

Salonen, H.; Lappalainen, S.; Lahtinen, M.; Nevala, N.; Lehtelä, J.; KnibBS, L.; Morawska, L. \& Rejula, K. (2011). Sisä̈mpäristön parantava ja elvyttä̈ä vaikutus hyvinvointipalvelutiloissa - Kir- jallisuuskatsaus. Helsinki, Finland; Työterveyslaitos.

SAlovaARA, J. (2013). Designing with emotions: empiric or empathic. In K. Niinimäki \& M. Kallio-Tavin (Ed.), Dialogues for sustainable design and art pedagogy the AH-design project, pp. 113-114. Helsinki, Finland: Aalto ARTS Books.

SANDERS, E. B.-N. \& StaPperS, P.J. (2008). Co-creation and the new landscapes of design. CoDesign, 4:1, 5-18, D0l: 10.1080/15710880701875068. Available at: http://dx.doi.org/10.1080/15710880701875068 (Accessed 30 September 2017).

SAndeRS, E. B.-N.; SoniCRIM. (2002). From User-Centered to Participatory Design Approaches. En J.Frascara (Ed.). Design and the Social Sciences. London: Taylor \& Francis Books Limited. Available at: http://maketools.com/articles-papers/FromUsercenteredtoParticipatory_Sanders_\%2002.pdf (Accessed 30 September 2017).

United Nations. (1990). The United Nations Convention on the Rights of the Child (UNCRC). Available at: http://www.ohchr.org/EN/Professionallnterest/Pages/CRC.aspx (Accessed 9 October 2017). 


\title{
Resumen.
}

Mi investigación jLe toca participar a los niños! Co-diseño educativo con niños investiga el papel de los niños y jóvenes en el diseño, y el derecho de los niños a participar e influir en la planificación, realización y desarrollo de servicios y medios dirigidos a ellos (UN 2009, Pollari 2016). Se trata de un caso de estudio que combina la investigación con la planificación y la organización de talleres de co-diseño para los niños y jóvenes (talleres Children's Turn). Esta investigación examina cómo el codiseño y la educación en diseño pueden promover los derechos de los niños en el diseño. El objetivo de los talleres Children's Turn (2014-2016) fue desarrollar métodos para fomentar la participación de niños y jóvenes. También desafiaron a los diseñadores y fabricantes de productos a desarrollar ideas de los niños y a ofrecer productos infantiles para un hospital. Algunos de los resultados de esta investigación fueron un marco pedagógico y herramientas de diseño creadas para los talleres. Estos fueron validados en talleres piloto y llevados a los talleres de codiseño para ayudar a la participación de los niños. Esta investigación sugiere el codiseño junto con la educación en diseño como una solución para cambiar las prácticas de diseño para apoyar la participación de los niños en el diseño. La idea de combinar educación en diseño y codiseño se probó entre los grupos de niños. Sobre la base de los buenos resultados de los talleres piloto, se organizaron talleres finales de codiseño en el entorno del museo para permitir la participación de los niños en el diseño de la ropa hospitalaria del New Children's Hospital en Helsinki.

Palabras clave. Participación; Derechos del niño; Diseño; Co-Diseño; Enseñanza del diseño; Museo.

\begin{abstract}
.
My research Children's Turn to Participate! Educational co-design with children investigates the role of children and young people in design, and children's rights to take part and influence the planning, realisation and development of services and milieus directed at them (UN 2009, Pollari 2016). It is a case study that combines research with planning and organising co-design workshops for children and young people (Children's Turn workshops). This research examines how co-design and design education might promote children's rights in design. The aim of the Children's Turn workshops (2014-2016) was to develop methods for fostering the participation of children and young people. They also challenged the designers and manufacturers of products to develop ideas from children and to offer children-based products for a hospital. A pedagogical framework and design tools created for the workshops were one of the outcomes of this research. Those were validated in pilot workshops and brought to the co-design workshops to aid children's participation. This research suggests co-design together with design education as a solution for changing design practice to support children's participation in design. The idea of combining design education and co-design, was tested amongst groups of children. Based on the good results of the pilot workshops, final co-design workshops were organized at the museum setting to allow children's participation in the design of the hospital wear of the New Children's Hospital in Helsinki.
\end{abstract}

Key-words. Participation; Children's rights; Design; Co-design; Design education; Museum. 